\title{
Student internships bridge research to real world problems
}

\author{
Michaela Hynie, Krista Jensen and Michael Johnny \\ York University, Toronto, Canada \\ Jane Wedlock \\ York Region Alliance to End Homelessness, Newmarket, Canada, and \\ David Phipps \\ Research Services and Knowledge Exchange, York University, Toronto, Canada \\ Reference: Education and Training (2011) vol. 53, no. 1, p. 45-56 \\ http://www.emeraldinsight.com/10.1108/00400911111102351
}

Emerald Group Publishing homepage: http://www.emeraldinsight.com/et.htm

\begin{abstract}
Purpose - The purpose of this paper is to evaluate whether unstructured graduate student research internships conducted in collaboration with community agencies build capacity and knowledge for students and community.

Design/methodology/approach - The paper reports the results of four semi-structured interviews and 20 pre- and post-internship surveys of students' perceptions of their internship activities; whether participation built research capacity in students and community resulted in the creation of new knowledge and promoted ongoing partnerships and relationships.
\end{abstract}

Findings - Students reported generating concrete outcomes for community partners, the acquisition of new research and professional skills, plus an increased understanding of theoretical knowledge. Many students also maintained ongoing relationships with their organizational partners beyond the terms of their internship.

Research limitations/implications - Limitations to this study are the relatively small sample size and reliance on self-report measures.

Practical implications - The paper describes a model for student-community engagement that benefits both community and students.

This article is (c) Emerald Group Publishing and permission has been granted for this version to appear here (http://www.emeraldinsight.com/10.1108/00400911111102351). Emerald does not grant permission for this article to be further copied/distributed or hosted elsewhere without the express permission from Emerald Group Publishing Limited. 
Social implications - As universities explore their relationships with their local communities, graduate student internships have tremendous potential for supporting research and knowledge-based needs of local communities, while providing valuable skills and training to a cohort of students in bridging academic research to real world solutions. These students may go on to be community engaged scholars, or research trained personnel in the community.

Originality/value - The results presented in this paper demonstrate the benefits to graduate students in scholarship of engagement programs that prioritize true partnership between students, universities and communities.

Keywords Graduates, Community relations, Knowledge processes, Canada, Partnership

Paper type Research paper

This article is (C) Emerald Group Publishing and permission has been granted for this version to appear here (http://www.emeraldinsight.com/10.1108/00400911111102351). Emerald does not grant permission for this article to be further copied/distributed or hosted elsewhere without the express permission from Emerald Group Publishing Limited. 
York University, Toronto is the third largest university in Canada, with a student enrollment of 50 686. York University promotes an interdisciplinary approach to learning, and has a strong commitment to social justice (http://www.yorku.ca/web/about_yorku/quick_facts.html). These values are reflected in its long history of community engaged scholarship and teaching and, most recently, in York’s leadership in Knowledge Mobilization (KMb) in the Canadian context. Reflecting its commitment to community engaged scholarship, the KMb unit offers student research internships that provide funding for graduate students to work collaboratively with community partners. As detailed elsewhere (Phipps \& Shapson, 2009) these internships are but one aspect of the KMb services provided by the KMb Unit. This paper reports an evaluation of whether these relatively unstructured internships succeeded in meeting their goals: to build research capacity among students and community partners; to create new knowledge; and to promote enduring community-student partnerships.

York is presently the only university in Canada with entrenched knowledge mobilization services within its institutional research framework. The KMb Unit originated as part of ResearchImpact, an ongoing collaborative project with University of Victoria, funded by the federal research granting councils. The goal of ResearchImpact is to "support the active, two-way exchange of information and expertise between knowledge creators and knowledge users" (http://www.researchimpact.ca/home/) in the areas of health and social sciences on a national scale. As the lead university for ResearchImpact, York's KMb Unit shares this mission but is focused on York University and the neighbouring York Region. The KMb Unit is part of a university wide strategy designed to connect university research with decision-makers and community organizations, in order to promote evidence informed public policy and/or professional practice (cf. SSHRC, 2008). It is this context that KMb provides a unique and valuable training opportunity for our students through its graduate internships.

\section{Knowledge Mobilization in Theory and Practice}

The term knowledge mobilization dates back to the 1990's in the field of education (Bhatti, n.d.). Knowledge mobilization is defined in a variety of ways but the core of these definitions includes three elements: the creation of knowledge, the use of knowledge, and the processes that connect knowledge creation and use (Levin, 2008; Mitton, Adair, Mckenzie, Patten, \& Perry, 2007; Phipps \& Shapson, 2009). This is distinguished from knowledge translation, in which knowledge creators merely transform their findings for transmission to knowledge users (Mitton et al., 2007).

Although building connections between research evidence and policy and practice is not new (Bonnen, 1998), interest in building these connections has increased dramatically in the last 30 years (Levin, 2008). With the increased activity comes a greater awareness of how to strengthen these connections, and ensure that research and evidence are taken up by policy makers, practitioners and the general public. One key theme that has emerged in successful strategies is the active involvement of stakeholders throughout the research process (CIHR, 2008). Although this may not be appropriate for all research endeavors, engagement of the user in knowledge creation has been found to increase the likelihood that the research will be relevant and put into action (Israel, Schulz, Parker, \& Becker, 1998).

This article is (c) Emerald Group Publishing and permission has been granted for this version to appear here (http://www.emeraldinsight.com/10.1108/00400911111102351). Emerald does not grant permission for this article to be further copied/distributed or hosted elsewhere without the express permission from Emerald Group Publishing Limited. 


\section{The York University Knowledge Mobilization Unit}

The KMb Unit at York University, Canada, has developed a knowledge broker model for promoting partnerships (Lomas, 2007; Phipps \& Shapson, 2009). The role of the knowledge broker is to bring together researchers in the university with knowledge users in the government or community, and to help direct them to possible sources of support for their research partnerships. Through a range of outreach activities, including community presentations, partnerships with governmental and not-for-profit organizations, and an interactive website, the York KMb Unit has solicited, received and acted on requests for research partnerships from community members and university researchers. Since 2006, 148 projects have been brokered, 37 of which have actively engaged or been led by students. An additional 24 partnerships were supported through graduate student internships, facilitated by dedicated funding in the KMb Unit's original grants. York students have made a significant contribution to building $\mathrm{KMb}$ as a credible and respected program for York, as well as, and more importantly, providing expertise and capacity to meet unique research and knowledge based needs of community agencies. The critical question for this paper, however, is how the engagement with community partners through these internships benefited these graduate students.

\section{Student Engagement and Engaged Scholarship}

Student engagement, community-university partnerships, service learning and experiential education are all commonly used terms to describe student education extending beyond the academy. The concept of student engagement emerges from the belief that universities the world over should be playing a role in civic engagement and in strengthening and supporting social responsibilities (Ostrander, 2004). The KMb Unit's approach to student engagement is grounded in the concept of engaged scholarship, which focuses on knowledge creation rather than on service provision (Barker, 2004; Boyer, 1996) and on the idea that practitioners and academic researchers possess different forms of knowledge and can learn from each other (Van de Ven \& Johnson, 2006).

Most student internships in North America occur in the context of service learning, where undergraduate or high school students integrate practice with specific subject knowledge by participating in required work-related activities for academic credit. The relationship is primarily between the community and academic institution, and the work is assigned to the students (Eyler, 2002; Rehling, 2000). In contrast, the York KMb internships were voluntary, self-directed and student initiated. Graduate students were equal partners in developing and carrying out jointly developed community research projects. Students did not get course credit towards their degrees and were not supervised by academic faculty. The focus on graduate students and emphasis on partnership is uncommon (cf. Savan \& Sider, 2003), and the students’ independence in choosing and developing their research partnership is, to our knowledge, unique.

This kind of equal participation in research partnerships should allow all members of the partnerships to build on their unique knowledge to improve both the quality and the relevance of the knowledge generated. This framing of student engagement emphasizes that the benefits of participation go beyond the acquisition of skills, practical application

This article is (c) Emerald Group Publishing and permission has been granted for this version to appear here (http://www.emeraldinsight.com/10.1108/00400911111102351). Emerald does not grant permission for this article to be further copied/distributed or hosted elsewhere without the express permission from Emerald Group Publishing Limited. 
of knowledge, and civic engagement (e.g. Astin \& Sax, 1998) to include the creation and understanding of new knowledge. Moreover, in contrast to criticisms that have been made of other approaches to student engagement, this approach should benefit the community as much as the student (cf. Barker, 2004), and promote sustained relationships between students and community partners, relationships that may themselves provide additional benefits, such as future employment, networking opportunities, and ongoing research collaboration potential (Rehling, 2000; Savan \& Sider, 2003).

More specifically, the York University graduate student internships were intended to achieve three goals:

1) Build research capacity: A primary goal of the KMb internships was to increase the skills and knowledge of students and community partners. The training of students would further contribute to community research capacity by training highly qualified personnel with a greater appreciation and understanding of research, and skills in finding and using relevant research in decision making and practice.

2) Create new knowledge: By working on projects developed in cooperation with their community partners, community interns would create new knowledge that meets the specific needs of their community partners and aligns with the student's program of graduate studies.

3) Promote partnerships: The relationships that developed between students and community partners would ideally be sustained outside of the work of their internship. This includes ongoing volunteer experiences as well as employment opportunities for students with their community partners following graduation and ongoing research partnerships.

\section{Methods}

\subsection{Participants}

In depth semi-structured interviews were conducted with four students who had received KMb internships. Two students were in the Department of Psychology, and two were enrolled in the Faculty of Environmental Studies.

Additional data were obtained from surveys distributed to all student recipients of internships in $2007(n=12)$ and $2008(n=12)$, at three time points: at application or start of the project, at completion of the project, and one year later. Not all respondents replied, and some replied to only a subset of the surveys, resulting in data from 20 successful student applicants, 19 of whom responded at Time 1 (program start), 15 of whom responded at Time 2 (program completion), and 9 of whom responded at Time 3 (1 year later). Student interns came from Environmental Studies (4), Geography (3), Psychology (4), Communication and Culture (2), Fine Arts (1), Music (1) and Women's Studies (1) (3 did not answer this question) and they partnered with agencies in several different sectors: government, NGO’s, labour, private sector and community-based service agencies.

\subsection{Procedures}

This article is (c) Emerald Group Publishing and permission has been granted for this version to appear here (http://www.emeraldinsight.com/10.1108/00400911111102351). Emerald does not grant permission for this article to be further copied/distributed or hosted elsewhere without the express permission from Emerald Group Publishing Limited. 
Applications for internships were considered during the summers of 2007 (42 applications) and 2008 (53 applications) for a four month part-time summer research internship. Applications needed to be jointly submitted by the student and their community organization partner. A stipend of $\$ 6000$ was awarded to the top 12 applicants each year. Applications were adjudicated by a committee of two York faculty and two local community representatives. Proposals were evaluated on demonstrated need, fit (between student study program and organization), work content and impact (the potential to mobilize knowledge and affect community decision-making).

The KMb Unit also offered an information session for interested applicants and offered to broker relationships for interested students who did not have an identified partner. The KMb Unit then hosted a session for successful students and their partners including a clear language writing workshop and a discussion of ethics protocols for the internship project. Upon conclusion of the internship, the students and their community partners reconvened to report on their collaborative efforts. Students and their community partners were responsible for jointly completing a two-page narrative report, a one-page summary report and participating in evaluation surveys.

The evaluation of the student internships was part of a larger evaluation of the entire $\mathrm{KMb}$ project. Only those materials and interviews pertaining to the student internships at the York University KMb Unit will be discussed here. The overall evaluation also included an examination of documents provided by the KMb team, including pre-existing internship surveys collected by the KMb team, which will be discussed in detail below. Results of the overall KMb evaluation, its review by an external, national level committee and York University's response to the evaluation is made available online at http://researchimpact.wordpress.com/2010/05/28/york-responds-to-the-knowledgemobilization-evaluation/.

Interviews: A semi-structured interview guide was developed, reviewed by the KMb evaluation advisory committee, and pilot tested with two community and two faculty participants. The schedule was revised following feedback from the pilot participants. Interviews were analyzed using thematic coding (Strauss \& Corbin, 1998). In the first step, preliminary codes were assigned according to the type of question asked. The coded data were examined by a second rater to ensure reliability and any discrepancies in the codes were resolved by discussion. The second step involved finding conceptual categories in the data, establishing relationships between categories, and deriving an account of the patterns observed.

Surveys: The surveys were developed by a KMb Unit staff member, a community partner, and a member of the evaluation team, and included both closed and open-ended questions about goals, products, skills acquired, and potential improvements. Critical closed-ended questions for the evaluation were self-ratings of respondents' general research knowledge, ability to utilize research, capacity to identify knowledge sources, and capacity to evaluate research. These four questions were measured on 7-point scales, ( 1 = Unsatisfactory and 7 = Very Satisfactory), and were asked at all 3 time points. Openended questions asked respondents to describe their hopes and goals for participating in the internship, new skills acquired, products/outcomes of the internship, and suggested improvements.

This article is (c) Emerald Group Publishing and permission has been granted for this version to appear here (http://www.emeraldinsight.com/10.1108/00400911111102351). Emerald does not grant permission for this article to be further copied/distributed or hosted elsewhere without the express permission from Emerald Group Publishing Limited. 
Means and standard deviations were calculated for closed ended questions and, where appropriate, t-tests are used to compare means. Open ended questions were subject to simple coding by two researchers and disagreements were settled by discussion.

\section{Results}

\subsection{Student goals for applying to the internship}

A total of 19 students responded to the Time 1 survey. Six themes emerged in the open-ended question about hopes for the internship. These are presented in Table 1. These themes can be classified into two broader classes in terms of their emphasis on the students' own development versus the impact on the community or organization.

Table 1. Themes in Student Interns’ Goals for Applying to the Internship Program

\begin{tabular}{|l|l|}
\hline \multicolumn{1}{|c|}{ Theme } & \multicolumn{1}{c|}{ Example } \\
\hline $\begin{array}{l}\text { Acquire academic } \\
\text { knowledge }\end{array}$ & $\begin{array}{l}\text { I hope to gain experience and knowledge that I can use in the } \\
\text { remainder of my academic program and in the work I do } \\
\text { afterwards. }\end{array}$ \\
$\begin{array}{l}\text { Learn about } \\
\text { community } \\
\text { organizations } \\
\begin{array}{l}\text { Network and } \\
\text { partnership } \\
\text { building }\end{array}\end{array}$ & $\begin{array}{l}\text { I hope to gain a better understanding of the structure and } \\
\text { community organizing. }\end{array}$ \\
$\begin{array}{l}\text { Improve } \\
\text { employability }\end{array}$ & $\begin{array}{l}\text { Hope to create long standing collaborations with community } \\
\text { partners to increase current and future capacity. }\end{array}$ \\
\hline $\begin{array}{l}\text { Community impact } \\
\text { Benefit the } \\
\text { community }\end{array}$ & $\begin{array}{l}\text { Work experience with a community organization. } \\
\text { Hope to provide effective and immediate knowledge } \\
\text { from it most. }\end{array}$ \\
$\begin{array}{l}\text { Help the } \\
\text { organization meet } \\
\text { its goals }\end{array}$ & $\begin{array}{l}\text { I hope that my research will help [the organization] improve } \\
\text { recommendations I have made based on the results of my study }\end{array}$ \\
\hline
\end{tabular}

Almost all students reported more than one theme and most students included themes from both of these two broader classes.

In terms of the impact of the internship on students themselves, acquiring academic knowledge was one of the most frequently mentioned themes. Students emphasized deepening their understanding of theoretical and applied questions, being published academically, furthering their academic careers by publishing and the desire to learn what the application of their theoretical knowledge would look like in the field. Interestingly,

This article is (c) Emerald Group Publishing and permission has been granted for this version to appear here (http://www.emeraldinsight.com/10.1108/00400911111102351). Emerald does not grant permission for this article to be further copied/distributed or hosted elsewhere without the express permission from Emerald Group Publishing Limited. 
very few students reported the goal of acquiring specific research skills; for almost all students who hoped to acquire academic knowledge, the emphasis was on the content of the research they would be conducting, rather than on the process of conducting that research. The second theme reflected several students' desire to learn more about the nature of NGOs, community organizations and government. They saw the internship as an opportunity to gain access to inside knowledge about how these organizations functioned, and how to work with them, or within them. The third theme reflected the desire to engage in network building in the sector, and on building and/or maintaining community partners. These relationships were discussed in terms of creating future opportunities for employment, for research dissemination, or for conducting additional research. Finally, the fourth theme reflected students' desire to acquire skills related to their future employment. This included gaining relevant work experience, professional skills, and, in one case, of hoping to be hired by their community partner.

The second class of themes described the impact students hoped to have on the community, or on their community partners. One of the most commonly mentioned themes was the desire to create positive change in the community and among the clients served by the organization. This included determining community or client needs, disseminating information and helping to change policy. The second theme in this class focused on the organization in particular. Several students spoke of wanting to help the organization meet its specific or general goals, such as doing a needs assessment, improving their website, or helping them meet their clients' needs.

Data from the semi-structured interviews generated similar findings. Students reported participating in these projects because they were interested in bridging the gap between academia and practice by facilitating the exchange of information and skills. They spoke of the desire to develop long-term relationships with their community partners, of broadening the network of researchers who were interested in a particular social issue and building the network of organizations engaged in frontline work. Finally, as with the survey respondents, some of the interview participants also reported being interested in exploring opportunities for future employment with community partners.

\subsection{Skills and knowledge acquired through the KMb internship}

Interview participants were asked about the benefits of this internship model. Students stated that the internship provided them with an opportunity that would not otherwise have been available to them. The internship funding for students provided an incentive for organizations to consider the possibility of integrating research with their daily operations:

If I hadn't been able to say [...], "I can come in here, York is going to pay me to work for you", then I may not have been able to get my foot in the door anywhere because just the idea of coming in and doing research within an organization is not as appealing if they're already short-staffed and feeling overwhelmed because they don't have time to engage in any kind of research even if it's collaborative (interview respondent).

This article is (c) Emerald Group Publishing and permission has been granted for this version to appear here (http://www.emeraldinsight.com/10.1108/00400911111102351). Emerald does not grant permission for this article to be further copied/distributed or hosted elsewhere without the express permission from Emerald Group Publishing Limited. 
Interview participants were able to further their own research interests while working on their projects and were able to contribute significantly to the work of the partner organization. The opportunity to apply their knowledge in a practical way, to learn about policy-making, and to lead (or co-lead) a major project were perceived to be unique and valuable as the students would not be able to gain such experience within their typical academic curriculum.

In terms of the survey, at the completion of the project, 12 (80\%) of the 15 students who responded to the Time 2 survey reported that the outcomes of the internship met their expectations. One year later, approximately half $(n=9)$ of the students completed the follow up survey. Five of these students had completed their thesis or dissertation by this time, and two of the five (40\%) reported that they had used community based research has part of their thesis/dissertation. Many of the students continued to have contact with their community partners one year after the completion of the internship $(\mathrm{n}=$ 7/9, 77.8\%). In fact, one year later, three participants reported currently being employed by the organization at which they had completed their internship [1].

In terms of the research skills reported in the survey, repeated sample t-tests were conducted separately on the four self-rating research knowledge measures. In light of the relatively small number of responses to Time 3, only Time 1 and Time 2 scores were compared [2]. Student interns evaluated their initial level of research knowledge as quite high (see Table 2). Students reported marginally higher levels of general research knowledge after completing the internship $(M=6.2)$, relative to the start of the internship $(M=5.6), t(12)=2.01, p=.07$, and a significantly greater capacity to identify sources of research following the internship $(M=6.2)$, relative to before $(M=5.6), t(12)=2.21, p=$ .05. There were no significant differences in reported knowledge of research utility, $t<$ 1 , or their capacity to evaluate research, $t<1$.

In the open ended survey questions about new skills, several students gave examples of concrete research skills acquired, such as learning to conduct interviews, develop surveys, and analyze focus groups. Other students noted that although they had research skills to begin with, the internship provided an opportunity to learn how to make research accessible and useful to a non-academic audience. For example, one student noted:

My role through the internship was to conduct research and write a report detailing the findings. While I have done research before and written papers, they have always been for an academic audience. This internship gave me the opportunity to learn how to write for a broader group of people- namely those working in social service agencies....now feel I have a much better understanding of the 'science' of recommendation writing (survey respondent).

Participation in the internships created an appreciation of the challenges and rewards of working in partnership. When discussing the new skills that they had acquired, several students remarked on how they had learned greater flexibility and adaptability, more comfort in working in community settings, and a deeper understanding of the goals, processes and challenges of applied settings, all characteristics that would strengthen their capacity to build future community partnerships. As one student put it, they learned

This article is (C) Emerald Group Publishing and permission has been granted for this version to appear here (http://www.emeraldinsight.com/10.1108/00400911111102351). Emerald does not grant permission for this article to be further copied/distributed or hosted elsewhere without the express permission from Emerald Group Publishing Limited. 
"An increased understanding of the intricate nature of existing partnerships and affiliations, and of the nature of bureaucratic processes” (survey respondent).

\subsection{Research products}

Students were asked about the quality and nature of the outputs of their internships. In the completion of project survey (Time 2), four main themes emerged in the 15 students' responses. Students generally reported that their research had benefited the organization and met the organization's goals, such as the dissemination of information to client populations, and the initiation of conversations within the organization regarding practice. A second theme was that students felt that they learned useful skills, such as how to work in a community organization, website development skills, and how to improve writing and presentation skills. A third theme was that students felt they had gained new knowledge about the issues they were addressing, such as homelessness or program evaluation. In the words of one intern:

Through this internship, I was able to help [the organization] improve their online resources while applying theoretical concepts from my program. This internship allowed me to put my Communication Studies research into action and I also gained a lot of valuable skills and knowledge about social issues and website development (survey respondent).

Table 2. Means and Standard Deviations of Self-Rated Knowledge at Three Time Points

\begin{tabular}{|l|c|c|c|c|c|c|}
\hline \multirow{2}{*}{} & \multicolumn{2}{|c|}{ Start } & \multicolumn{2}{c|}{ Completion } & \multicolumn{2}{c|}{1 year later } \\
\cline { 2 - 7 } & \multicolumn{2}{|c|}{$n=19$} & \multicolumn{2}{c|}{$n=13$} & \multicolumn{2}{c|}{$n=8$} \\
\hline $\begin{array}{l}\text { Rean } \\
\text { knowearch }\end{array}$ & 5.7 & 0.82 & 6.2 & 0.69 & 5.4 & 1.5 \\
\hline $\begin{array}{l}\text { Research } \\
\text { utility }\end{array}$ & 5.4 & 1.2 & 5.5 & 1.6 & 4.9 & 1.5 \\
\hline $\begin{array}{l}\text { Identifying } \\
\text { sources }\end{array}$ & 5.8 & 0.83 & 6.2 & 0.69 & 5.5 & 1.6 \\
\hline $\begin{array}{l}\text { Evaluating } \\
\text { research }\end{array}$ & 5.7 & 0.89 & 5.8 & 0.93 & 5.1 & 1.8 \\
\hline
\end{tabular}

\subsection{Adequacy of student training and suggestions for improvement}

Students were generally very positive about the internships, but also had suggestions for how the experience could be improved. These suggestions fell into the three main categories. First, students wanted more contact with other KMb interns, noting that they could have learned from each others' experiences. As one student wrote in their survey:

I would like to have an opportunity to interact more with the KMb Interns. It might be interesting and advantageous to share knowledge and /or resources with other students and faculty in the program (survey respondent).

This article is (c) Emerald Group Publishing and permission has been granted for this version to appear here (http://www.emeraldinsight.com/10.1108/00400911111102351). Emerald does not grant permission for this article to be further copied/distributed or hosted elsewhere without the express permission from Emerald Group Publishing Limited. 
Second, while students were very positive about the skills they had acquired, some felt that they needed more mentorship and formalized training in regards to professional skills. Consistent with their generally high evaluations of their basic research skills at the outset, only one student suggested needing more support for the research process, but several students in the surveys and interviews suggested that they would have liked more training in professional skills and more mentorship around establishing relationships with community organizations. It was suggested that interns be matched with faculty mentors to show you "this is an intellectual way, or this is a fair and equitable way of going about things" (survey respondent), especially if they were engaged in an area of research that was not complemented by that of their supervisors.

Finally, several students in both the surveys and interviews noted that they felt they needed more time for their projects. This was especially true when students did not have the advantage of prior personal contact with the organization, or were not previously exposed to community-based research. The challenge of completing a four month internship was compounded by the fact that the internship occurred in the summer, which is not an ideal time for community partners:

When you give someone four months to engage in community work, it's too short. I know that it's because those are the four months of summer that we are meant to be in the field more and not be doing courses [...] it makes sense in an academic timeline but it doesn't make sense in the world of community work.... (interview participant)

\section{Discussion and Conclusions}

Consistent with the KMb Unit goals and findings from undergraduate student internship programs (e.g., Astin and Sax, 1998; Rehling, 2000), graduate student interns reported that they learned new skills, maintained partnerships with their community partners and built new networks and relationships. Importantly, they also generated new knowledge in partnership with the community, and recognized the different forms of knowledge that existed in the community and academia, both of which define engaged scholarship and the principles of knowledge mobilization (Baker, 2004). Moreover, they achieved this in a self-directed, voluntary internship, rather than through an internship integrated into a formal curriculum.

Students believed they had strong general research skills at the outset of the internships. Not surprisingly then, few reported hoping to acquire research skills but rather, focused on deepening their theoretical or disciplinary knowledge. Students did report learning more about their own fields of expertise but many also reported that the internship helped them build and refine specific research skills such as survey design or qualitative data analysis. It is possible that they initially underestimated how much they could learn about research in a non-academic community setting and how much relevant knowledge the community possessed emphasizing the value of internships for promoting recognition of community knowledge.

Students described learning a wide range of professional skills that they anticipated applying in their future careers. Similarly, students reported being motivated by an interest in making professional connections and a desire to find employment, which is not

This article is (C) Emerald Group Publishing and permission has been granted for this version to appear here (http://www.emeraldinsight.com/10.1108/00400911111102351). Emerald does not grant permission for this article to be further copied/distributed or hosted elsewhere without the express permission from Emerald Group Publishing Limited. 
surprising given that so many graduate students pursue non-academic careers (Bloom, 2009). The relationships developed could also later assist in, or lead to, employment.

More generally, at least 14 students maintained ongoing relationships with these not-forprofit agencies regardless of employment opportunities, showing how internships can provide a strong grounding for ongoing civic engagement (Ostrander, 2004; Rehling, 2000).

Critically, from the perspective of the KMb Unit, these internships provided a genuine benefit to the community partners. Most of the students were motivated by a desire to create positive change for the community and/or the organization they partnered with and, indeed, the students reported a range of important and useful outcomes to their research. Although space limitations prevent the reporting of the results here, similar interviews and surveys conducted with community partners confirmed students' evaluations of the internships' usefulness. Because student interns sustained these relationships after the internship was completed, opportunities for additional knowledge coproduction in the future were also created.

The students made several excellent suggestions for improving the internships, many of which are consistent with Eyler's (2002) call for the need for reflection to allow service learning to deepen students' understanding of social issues and dealing with complex social problems. These included having a longer period of time in which to partner, perhaps during the school year rather than the summer, and the addition of mechanisms for more mentorship, both from each other and from faculty. These changes could benefit students and community partners alike.

Students' improved skills and knowledge were only being measured through selfreport, and more objective measures of these changes would be preferred. Moreover, the sample of students is small and may reflect only the perceptions of students who were already interested in and committed to this kind of scholarship. The large number of applications for this novel program (100 in 2 years) suggests that the desire for this kind of engagement among graduate students is quite strong but it is not clear if these benefits would extend to students who did not share these interests.

With these limitations in mind, however, we feel that the KMb Unit was successful in meeting its objectives of creating engaged scholarship through self-directed graduate student research internships. We have increased students’ knowledge, skills, and opportunities for employment; we positively influenced the community's capacity for conducting and applying research; and we expanded the range of ways in which the university can partner with the community, benefitting students, communities, universities, and society as a whole.

This article is (c) Emerald Group Publishing and permission has been granted for this version to appear here (http://www.emeraldinsight.com/10.1108/00400911111102351). Emerald does not grant permission for this article to be further copied/distributed or hosted elsewhere without the express permission from Emerald Group Publishing Limited. 


\section{Notes}

1. A follow up e-mail sent to the 24 students in 2009 by the KMb Unit found that 14 of 19 students who responded had a continued relationship with their community partners.

2. The apparent decrease in the means at the one year follow up (Time 3) was explored despite being based on only half of the original sample. Time 3 means did not differ significantly from the Time 2 data (all $t s<1.17$ ). The means are unduly influenced by a single participant who evaluated herself very highly at Time 1 and 2 but at Time 3 rated herself very low. It is unclear why this student's self-ratings altered so drastically at Time 3 since her open ended responses remained positive.

This article is (c) Emerald Group Publishing and permission has been granted for this version to appear here (http://www.emeraldinsight.com/10.1108/00400911111102351). Emerald does not grant permission for this article to be further copied/distributed or hosted elsewhere without the express permission from Emerald Group Publishing Limited. 


\section{References}

Astin, A. W. \& Sax, L. J. (1998), "How undergraduates are affected by service participation”, Journal of College Student Development, Vol. 39 No. 3, pp. 251-263.

Barker, D. (2004), “The scholarship of engagement: A taxonomy of five emerging practices”, Journal of Higher Education Outreach and Engagement, Vol. 9 No. 2, pp. 123-137.

Bhatti, T. (n.d.), “SSHRC and Knowledge Mobilization”, available at: http://www1.unitedway.ca/sites/PortalEN/PublicSite/EVENTS\%20AND\%20MEETING S/SSHRC\%20\%20Knowledge\%20Mobilization_May\%202008_1.pdf (accessed 29 January 2010).

Bloom, K. (2009), "Science policy in Canada: the Lavalife of science”, The Mark, October 23, 2009, available at: http://themarknews.com/articles/615-the-lavalife-ofscience (accessed 29 January 2010).

Boyer, E. (1996), “The scholarship of engagement”, Journal of Public Service and Outreach, Vol. 1 No. 1, pp. 11-20.

Canadian Institutes of Health Research (2008), Knowledge to action: A knowledge translation casebook, Government of Canada.

Eyler, J. (2000), "Reflection: Linking service and learning-linking students and communities”, Journal of Social Issues, Vol. 58 No. 3, pp. 517-534.

Israel, B., Schulz, A. J., Parker, E. A., \& Becker, A. B. (1998), "Review of community-based research: Assessing partnership approaches to improve public health”, Annual Review of Public Health, Vol. 19, pp. 173-202.

Levin, B. (2008), “Thinking about knowledge mobilization”, Paper prepared for an invitational symposium sponsored by the Canadian Council on Learning and the Social Sciences and Humanities Research Council, Ontario Institute for Studies in Education, Toronto, pp. 1-31.

Lomas, J. (2007), “The in-between world of knowledge brokering”, British Medical Journal, Vol. 334 No. 7585, pp. 129-132.

Mitton, C., Adair, C., McKenzie, E., Patten, S., \& Perry, B. (2007), “Knowledge transfer and exchange: Review and synthesis of literature”, The Millbank Quarterly, Vol. 85 No. 4, pp. 729-768.

This article is (c) Emerald Group Publishing and permission has been granted for this version to appear here (http://www.emeraldinsight.com/10.1108/00400911111102351). Emerald does not grant permission for this article to be further copied/distributed or hosted elsewhere without the express permission from Emerald Group Publishing Limited. 
Ostrander, S. A. (2004), "Democracy, civic participation, and the university: A comparative study of civic engagement on five campuses”, Nonprofit and Voluntary Sector Quarterly, Vol. 33 No. 1, pp. 74-93.

Phipps, D. J. \& Shapson, S. (2009), "Knowledge Mobilisation builds local research collaborations for social innovation", Evidence \& Policy: A Journal of Research, Debate and Practice, Vol. 5 No. 3, pp. 211-227.

Rehling, L. (2000), “Doing good while doing well: Service learning internships”, Business Communication Quarterly, Vol. 63 No. 1, pp. 77-89.

Savan, B. \& Sider, D. (2003), “Contrasting approaches to community-based research and a case study of community sustainability in Toronto, Canada”, Local Environment, Vol. 8 No. 3, pp. 303-316.

Social Sciences and Humanities Research Council (2008), "Scholarship in action: Knowledge mobilization and the academic process”, Dialogue, Summer 2008, available at: http://www.sshrc.ca/newsletter/2008summer/knowledge_mobilization_e.asp (accessed 29 January 2010).

Van de Ven, A. H. \& Johnson, P. E. (2006), "Knowledge for theory and practice", Academy of Management Review, Vol. 31 No. 4, pp. 802-821.

This article is (c) Emerald Group Publishing and permission has been granted for this version to appear here (http://www.emeraldinsight.com/10.1108/00400911111102351). Emerald does not grant permission for this article to be further copied/distributed or hosted elsewhere without the express permission from Emerald Group Publishing Limited. 